Druzsin József ${ }^{1}$

\title{
A 100 ÉVES MÁTYÁSFÖLDI REPÜLÖTÉR KATONAI, REPÜLÉS- ÉS GYÁRTÁSTÖRTÉNETI, VALAMINT KATONAI LOGISZTIKAI EMLÉKEI
}

\author{
II. rész
}

DOI: $10.30583 / 2018 / 1-2 / 275$

\section{A mátyásföldi repülötér szerepe a Repülőgépgyár Rt. tevékenységében ${ }^{2}$}

Az 1942 novemberében alapított és 1943 januárjában bejegyzett Repülőgépgyár Rt. nevü cég részvényeinek 51\%-át Uhry Imre, 39\%át pedig Uhry Zsigmond jegyezte. ${ }^{3}$ Bár eredetileg Csepelen kezdték meg működésüket, és ott tervezték az Uhry gépjármükarosszériagyárat is elhelyezni, ${ }^{4}$ de a csepeli légiveszély miatt a Honvédelmi Minisztérium máshol kívánta felépíteni a gyárat. ${ }^{5} \mathrm{Az}$ Uhry testvérek gyárának Mátyásföldre történő telepítése során a fővárosi helyszínek közül a háborús viszonyok között ideálisnak mondhatót sikerült kiválasztani. A mátyásföldi repülőtér 700x800 m-es füves pályával, kiszolgálóépületekkel, hangárokkal rendelkezett, 12,5 km-re volt Budapest városközpontjától. ${ }^{6} \mathrm{~A}$ csepeli Weiss Manfred repülötéren elhelyezett Repülőgépgyár Rt. a nyersanyagok és alkatrészek beszállításának folyamatos késedelme mellett helyhiánnyal is küzdött.

1 A szerző hivatásos honvéd százados a repülőműszaki logisztika területén tevékenykedik az MH Logisztikai Központ állományában.

E-mail: druzsin.jozsef@gmail.com

2 Fábián András - Ozsváth Sándor: A magyar tervezésű és gyártású Levente II. kiképző repülőgép és légialkalmas másolatának megépítése III. rész Haditechnika 2016/5. szám

3 MNL OL Z.516 1. cs. 1. t.

4 MNL OL Z.516 1. cs. 9. t. - Pro Memoriam a Repülőgépgyár Rt. üzembővítésével kapcsolatban, 1943. november 12.

5 HL HM 1943 Eln. 17/r oszt. - Fabarakk épületek felállításával kapcsolatos pro domo iratokban Uhri Imre levele, 1942. december 16.

680 éves a Mátyásföldi Repülőtér Corvin Hírnök Bp., 1996. 
A használatban lévő épületek mellé ezért újabb faszerkezetű hangárt építettek fel, mert már ekkor látszott, hogy a mátyásföldi nagycsarnok - melyben a sorozatgyártást nagyobb kapacitással tervezték végezni - 1944 márciusára sem lesz beköltözhető. Az első tíz darab Levente II. repülőgépet még Csepelen adták át (a gépek I.551-től I.560-ig kaptak katonai lajstromjelet). Az 1944. április 3-án Csepelt ért légitámadás ${ }^{7}$ után a $\mathrm{HM}$ elrendelte a Repülőgépgyár Rt. azonnali átköltöztetését a mátyásföldi, még építkezés alatt álló gyártelepre. ${ }^{8} \mathrm{~A}$ bombázások során a Repülőgépgyár Rt. mátyásföldi telepe nem szenvedett jelentős sérüléseket, ám a gyár fökonstruktőre, Fábián András is egy Budapestet ért bombatámadásban vesztette életét. ${ }^{9}$

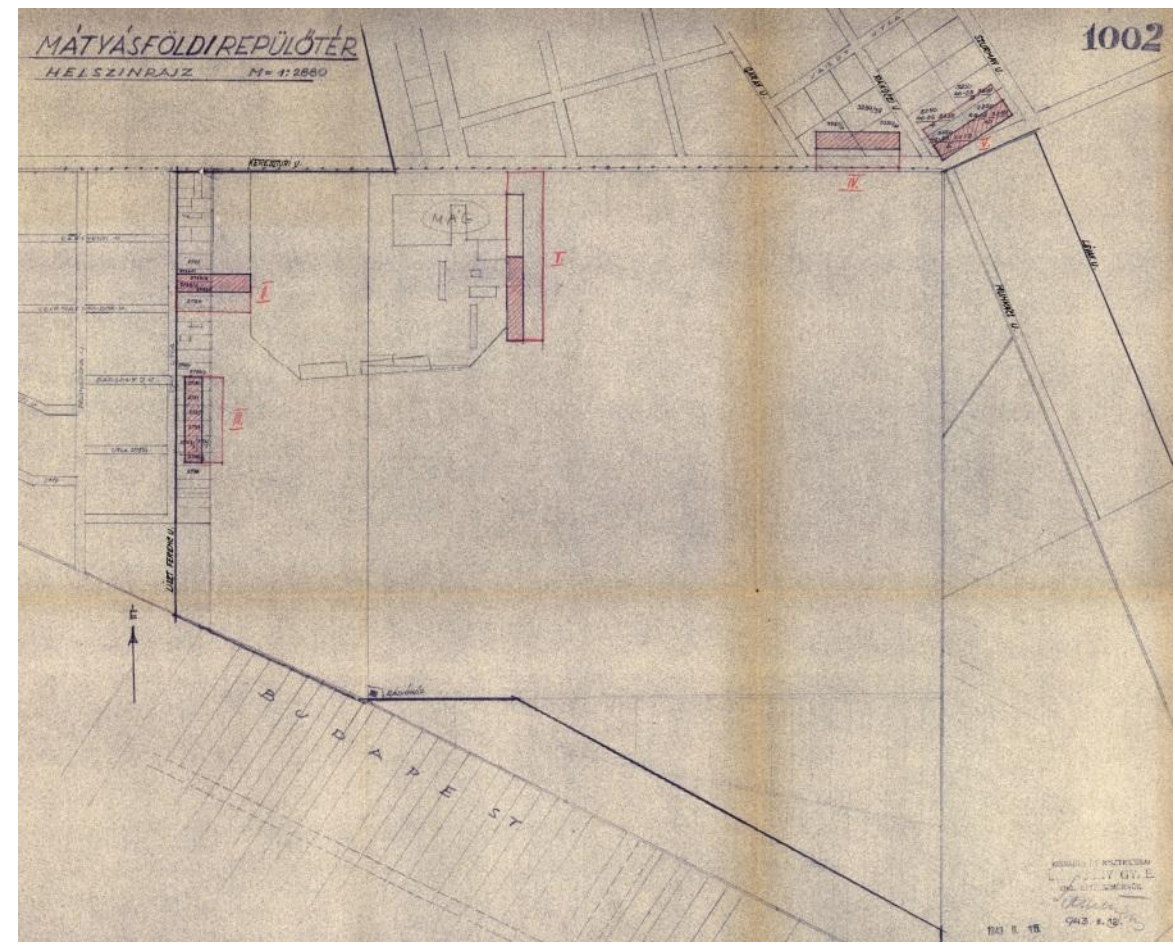

14. számú ábra. A Repülögépgyár Rt. Honvédelmi Minisztériumnak benyújtott tervei a végszerelde épületének helyszínéröl 1943 februárjából. A HM az l. számú elhelyezést választotta ${ }^{10}$

MNL OL Z.516 2. cs. 25. t. - Repülőgépgyár Rt. helyzetjelentés, 1944. május 27.

8 MNL OL Z.516 2. cs. 25. t. - A HM engedélyezi a gyár azonnali átköltöztetését Mátyásföldre, 1944. április 5.

9 Fábián András gyászjelentése saját hagyatékából, 1944. július 20.

10 HL HM 1943 ELN 17/r oszt. - A Repülőgépgyár végszereldéjének elhelyezésével kapcsolatos pro domo iratok 
A Repülőgépgyár Rt. 1944 tavaszától fokozatosan költözött át Csepelről mátyásföldi új telephelyére, a Margit utcába. ${ }^{11} 1941$-ben a Horthy Miklós út (ma Kerepesi út) átellenes, északi oldalán lévő, munkás és tisztviselő lakókörzetnek számító Új Mátyásföldnek elnevezett területen voltak még olyan parcellázatlan, lakókörzettöl távol eső és céljaiknak megfelelő szántóföldek, amelyekre felépíthető volt az Uhry testvérek repülögépgyára.

A gyár végszereldéjét a mátyásföldi repülötér északnyugati részén helyezték el, ${ }^{12}$ ezért a gyárból a végszerelésre szánt gépeket (leszerelt szárnnyal) a főút túloldalán lévő mátyásföldi repülőtérre vontatták át: itt végezték a berepüléseket és itt történtek a RÁB átvételek is. ${ }^{13} \mathrm{~A}$ gyár tehát a legendássá vált Levente II. repülőgépeket gyártotta ekkor, és a mátyásföldi repülőteret használta berepüléseihez. A Levente II. gyártása szempontjából ideális volt a környék ipari jellege. A terület nem csak közúton, hanem vasúton is megközelíthető volt (Rákos Vasútállomásról közvetlen iparvágány vezetett a repülőtér déli részéhez, akárcsak a föúton futó HÉV sínektöl a Fokker úton át).

Érdekes kísérletnek tekinthető a Repülőgépgyár Rt. által Fábián András tervei alapján gyártott „Honvéd” kétmotoros gyakorló repülögép. A MÁVAG-Hirt HM504-es, 105 LE-s motorokhoz a gyár 194344-ben vegyes építésű, vászonborítású, könnyű gyakorló- és futárcélú repülőgépet épített. A 12,3 méteres fesztávú, 880 kg üres töme-

11 MNL OL Z.516 2. cs. 25. t. - A HM engedélyezi a gyár azonnali átköltöztetését Mátyásföldre, 1944. április 5.

12 HL HM 1943 ELN 17/r oszt. - A Repülőgépgyár végszereldéjének elhelyezésével kapcsolatos pro domo iratok.

13 A repülőműszaki területen az állami átvételi folyamatokat jelentősen befolyásoló eseményként 1935-ben létrehozták a Magyar Királyi Honvéd Légierő Repülőgép Kísérleti Intézetét (RKI) a Weiss Manfréd gyár csepeli repülőterén. A Repülökísérleti Intézet a Magyar Királyi Honvéd Légierő repülőeszközeinek haditechnikai biztosításában (beszerzésében, vizsgálataiban, kutatás-fejlesztésében, üzembentartásában) játszott jelentős szerepet. Emellett jelentős volt az RKI szerepe a repülőipari minőségbiztosításban is. Többfajta, gyártásközi ellenőrzéssel, végátvétellel és állami átvételi tevékenységgel kapcsolatos minőségügyi feladatot is ellátott akkor, amikor szakembereket képzett és delegált a gyártóknál működő Repülő Átvételi Bizottságokba (RÁB), gyári berepülőpilótákat képzett, illetve végezte a repülőgépgyártóktól beérkező új repülőgépek minőségi átvételi vizsgálatait. A Katonai Átvételi Bizottság (KÁB) szakterületi képviseletét a Magyar Királyi Honvéd Légierő eszközei tekintetében a Repülő Átvételi Bizottságok (RÁB) látták el, amelyek központi szervezete az RKI szervezetén belül került kialakításra. 
gü, „üvegház” kabintetős gép berepülése folyamatban volt, ám teljes befejezése a háborús események miatt elmaradt. ${ }^{14}$

Ugyancsak a háború vetett véget a Varga László által, a Repülő Müszaki Intézetben tervezett RMI-7 „V/G” elnevezésű kiképzőgép gyártásának is. A 450 LE-s Argus AS 410 típusú motorral szerelt repülőgépek a Me-109-es gépekre történő pilóta- átképzést szolgálták volna, hiszen azonos futószerkezettel és - a Me-109-esssel mindenben megegyező - szimulátor kabinberendezéssel épültek volna. ${ }^{15}$

A Repülögépgyár Rt. MÁG mellett felállított végszereldéje a mátyásföldi reptéren először fabarakkokban települt, majd végleges épületet kezdtek építeni, azonban ezt 1944 júniusában le kellett állítani. 1944 decemberének végén intézkedtek a reptéri fabarakkok kitelepítéséről. A légiveszélyt tekintve a gyár végül kisebb sérülésekkel átvészelte a háborút, direkt bombatámadást soha nem is szenvedett.

A szovjet csapatok közeledésével - mivel a Ferihegyet ért támadás olyan súlyos károkat okozott - a pesti oldal légi ellátásának egyik elsődleges színtere néhány hétre Mátyásföld lett. ${ }^{16} \mathrm{~A}$ Levente II. repülőgépek gyártása az ostrom alatt sem szünetelt, noha 1944 októberére a szovjet csapatok elérték Budapest határát. A HM Mizsér Jenő műszaki igazgató javaslatára ${ }^{17}$ november 25 -én nyílt parancsba adta ${ }^{18}$ a gyár azonnali kitelepítését a pápai repülötér közelében elhelyezkedő Szélmezőpusztára. ${ }^{19} 1944$ novemberében a HM a mátyásföldi építkezést rendeletileg beszüntette. ${ }^{20}$ December 6-ára a 238 före csökkent munkáslétszámból 64-en még erőltetett ütemben a Levente II.-k szerelésével foglalkoztak, a többiek a kitelepítés végrehajtásán

14 Winkler László: Magyar konstrukciók Rákostól napjainkig 18. Repülés 1968/10. szám

15 Winkler László: Magyar konstrukciók Rákostól napjainkig 19. Repülés 1968/11. szám

16 Turcsányi Károly - Hegedűs Ernő: A magyar légideszantcsapatok alkalmazásának, haditechnikai eszközeinek és szervezetének fejlődése (1933-45) I-II. rész Katonai Logisztika 2016. évi 3-4. sz. BFL XVII.622 - Mizsér Jenő müszaki igazgató helyzetjelentése, 1944. december 20. MNL OL Z.516 1. cs. 10. t. - A HM nyílt parancsa a Repülőgépgyár Rt. Szélmezőpusztára való kitelepítéséről, 1944. november 25.

19 BFL XVII.622 - Mizsér Jenő müszaki igazgató helyzetjelentése, 1944. december 20.

20 MNL OL 1. cs. 15. t. - Repülőgépgyár Rt. igazgatósági ülésén készült jegyzőkönyv, 1947. november 10. 
dolgoztak, a munkások az ellenséges repülőgépek ágyúzása és aknatüz közepette végezték munkájukat. A gyár gépeit, felszerelését, anyag- és félkészáru-készleteit részben teherautókon, részben pedig 25 vasúti vagonba rakva indították útnak. A kitelepítésre tervezett anyagból csak 6 vagon érkezett meg Pápára, ${ }^{21} 19$ vagon pedig Köbánya alsó és Rákosrendező között rekedt, mert Budapest körül bezárult a szovjet ostromgyűrü. ${ }^{22} \mathrm{~A}$ cégvezetés célja ezután már csak az volt, hogy a reménytelen körülmények között épülő iskolagépekböl minél többet be tudjanak fejezni és kijuttassanak az összeomló Budapeströl. ${ }^{23}$

A Repülögépgyár Rt. utolsó helyzetjelentéséböl, melyet a HM-nek 1944. december 20-án Mizsér Jenő müszaki igazgató írt, kiderül, hogy V. 20 db-os szériából (az eddig legyártott darabszámok alapján I.631-I.650-ig terjedő jelzéssor) is sikerült $5 \mathrm{db}$ előszerelés alatt álló gépet úgy elkészíteni, hogy azok saját szárnyukon hagyták el a mátyásföldi repülőteret kitelepülési helyükre. Összesen $18 \mathrm{db}$ új és javított gépet repültek át Dég, Esztergom, Türje, Pápa, Tapolca repülőterekre. Miután elrendelték a mátyásföldi repülötér katonai kiürítését, az V. $20 \mathrm{db}$-os szériából további $5 \mathrm{db}$ gépet a budapesti Vérmezőn kialakított ideiglenes repülőtérre szállították át olyan állapotban, hogy azokra már csak a szárnyakat kellett felszerelni. ${ }^{24} \mathrm{Az}$ utolsó Mátyásföldön szerelt 5 db Levente II. tehát 1944 decemberében szállt fel a mátyásföldi repülőtérről, majd - Budapest szovjet körülzárásakor december 30 -án a repülötér elesett. ${ }^{25}$

1945 után Mátyásföldön a repülögépgyártás ellehetetlenült. A Repülőgépgyár Rt. mátyásföldi gyárkomplexumát az Uhry karosszéria

Uo. és MNL OL Z.516 1. cs. 15. t. - Repülőgépgyár Rt. igazgatósági ülés jegyzőkönyv, 1947. november 10. MNL OL Z.516 1. cs. 15. t. - Repülögépgyár Rt. igazgatósági ülés jegyzőkönyv, 1947. november 10.

BFL XVII.622 - Mizsér Jenő műszaki igazgató helyzetjelentése, 1944. december 20. Bizonyítja, hogy a Levente II. programot nem állították le: 1944 végéig erőltetett ütemben folyt a gyártás, amit a kitelepítési helyen még 1945-ben is folytatni szándékoztak

24 BFL XVII.622 - Mizsér Jenő műszaki igazgató helyzetjelentése, 1944. december 20.

25 BFL XVII.622 - Mizsér Jenő műszaki igazgató helyzetjelentése, 1944. december 20. 
gyár bérelte ki, és itt próbálta fenntartani működését $1947-$ ig $^{26}$ - komoly nehézségek között -, amikor is a gyár az államosított vállalatokat irányító Nehézipari Központ (NIK) kezébe került. Ezt követően a Repülőgépgyár Rt., az Uhry cég és a repülögép- és autóipari alkatrészeket gyártó Ikarus Gép- és Fémgyár Rt. egyesítésével a mátyásföldi telephelyen 1949. február 23-án létrehozták a jól ismert állami lkarus Karosszéria- és Jármügyárat. ${ }^{27}$

A Levente II. típusú repülőgépek háború utáni történetének szempontjából is fontos szerep jutott Mátyásföldnek. Az 1945 és 1990 közötti időszakban a Szovjet Déli Hadsereg Csoport és az 59. Légihadsereg főparancsnoksága üzemeltette a füves repülöteret. 1945 után a HM próbálta begyújteni azt a sérült repülőgép-anyagot, amely még megtalálható volt. A mátyásföldi repülöanyag-raktárba gyűjtötték össze a különböző állapotban fellelt, elsősorban kiképző és iskola repülőgépeket, így a Levente II. típusból is került ide sérült gép, ill. fődarabok.

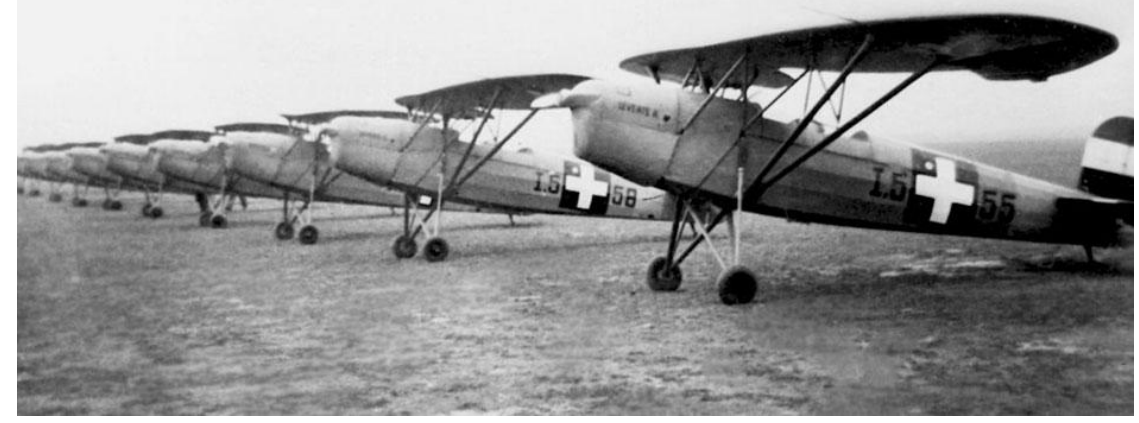

15. számú ábra. Az első 10 db-os Levente II. kisszéria átadása még a csepeli repülőtéren 1943 novemberében. ${ }^{28}$ 1944-től az Uhry testvérek új mátyásföldi repülögépgyárának végszereldéjét már a mátyásföldi repülőtér észak-nyugati részén helyezték el, és itt végezték a berepüléseket, átadásokat is

MNL OL Z.517 1. cs. 5. t. - Jelentés az Uhry gyár általános helyzetéröl, múltjáról, 1947. június 16. és MNL OL Z.516 1. cs. - Számos jegyzőkönyv a Repülögépgyár Rt. igazgatósági üléseiről

Gerlei Tamás-Kukla László-dr. Lovász György: Az lkarus évszázados története. 3., javított és bővített kiadás. Maróti Kiadó. Bp., 2007. 21. o.

MNL OL Z.516 1. cs. 17. t. - Repülögépgyár Rt. helyzetjelentés, 1943. november 25 . 
A II. világháború után, 1947-töl itt müködött az 1. Honvéd RepüIőtér Gondnokság és a Honvéd Repülögép-javító Mühely, valamint itt alakult meg az újjászerveződő katonai repülés első alakulata: az 1. Önálló Repülőszázad is. Végül - a Levente II. kivételével egyetlen begyűjtött repülögépet sem javítottak ki Mátyásföldön, ezeket valamikor 1947-ben feldarabolták. ${ }^{29}$

1948 közepén aktuálissá vált a Haditechnikai Intézet Repülő osztályának felállítása, melynek elhelyezése Mátyásföldön történt, Repülő Kísérleti Állomás (RKA) néven. ${ }^{30} \mathrm{~A}$ múszaki munkákat itt már 1948ban megkezdték: gépek berepülése, motorvizsgálatok végzése, atrap-bombák készítése stb. A HA-LEB jelzésű Levente II. felújítását 1949 szeptemberére fejezték be. ${ }^{31}$

A háború utáni autóbusztípusok karosszériáját az Uhry testvérek karosszériagyárának utódjaként létrehozott Ikarus készítette. Ez a mátyásföldi gyár biztosította a MÁVAG (Magyar Királyi Állami Vas-, Acél- és Gépgyárak) utolsó sorozatában készített B5 típusjelzésü 5 tonnás honvédségi teherautó alvázához a vezetőfülkéket is. ${ }^{32}$

\section{Katonai logisztikai szervezetek Mátyásföldön}

A mátyásföldi repülőtér története elválaszthatatlan a katonák jelenlététől, legyen szó katonai repülőgépgyártásról, javításról, ejtőernyős ugrásokról, repülőalakulatok szervezéséről, a Magyar Királyi Légierő születéséről, vagy éppen gépjárművek gyártásáról, tárolásáról. Amint azt a fentiekben a MÁG és az Uhry gyárak esetében kimutattuk, ezek működése, termelése ezer szállal kötődik a Honvédség tevékenységéhez. A katonai repülö- és gépjármüves kiképzések is jelen voltak Mátyásföldön, ahogy arra az alábbiakban részletesen is kitérünk. Gépjárműves kiképzési példaként említhető, hogy a hivatalos honvédségi "gépkocsizó kiképzés" a 30-as években kezdődött a BudaA létszáma 35 tiszt, 15 tiszthelyettes és 5 írnok. Az állomást az Intézet hatásköréből 1950 januárjában vonták ki (az állományt átadták a REMI-nek Tökölre) Dr. Hajdú F.-Sárhidai Gy.: A Magyar Királyi Haditechnikai Intézettől a HM Technológiai Hivatalig HM TH Budapest, 2005.

31 Repülés- és Üzemtörténeti Kör, XVII. Konferencia. 1992. Gibás Andor: Fábián "Levente".

32 http://budapestcity.org/02-tortenet/Budapest-gyarai/index-hu.htm 
pest-Mátyásföldi laktanya Gépkocsizó Tanezrede szervezésében. A Magyar Honvédség gépjárművezetői állományának kiképzése a háború alatt és után is Mátyásföldön zajlott, ill. néhány hadtestnél az Állami Sofőriskola, majd az Autóműszaki Intézet is besegített. 1949ben még folyt mümesteri tanfolyam Mátyásföldön, a honvédségi gépjármü szertárban, ahol korábban a Gépkocsizó Tanezred állomásozott (1949. május 30-tól, október 16-ig, a négy és fél hónapos mümesteri tanfolyamon Szilvai örnagy és Pénzes föhadnagy oktatókkal.) Nem mindennapi fegyelmet tartottak: megkövetelték a hallgatóktól, hogy mindig tisztelgéssel és "Víz, Olaj, Levegő!" hangos köszöntéssel üdvözöljék egymást. ${ }^{33} \mathrm{~A}$ feladatot az 50 -es évek elejétől a Budapest, Zách utcai laktanyában müködő „Gépkocsizó Tiszti Iskola" vette át.

\subsection{Gépjármútechnikai logisztikai szervezetek Mátyásföldön a II. világháború után}

A Honvédség jelenlegi mátyásföldi telephelyén már 1939-töl kezdve müködött katonai logisztikai szervezet. $A X X$. század elején, a robbanómotorok elterjedésével a hadseregben is megjelentek a kiépített utak hiányában is manőverezni tudó, gép- és harcjármüvek. A felmerülő problémák orvoslására, a harcanyag és a technikai eszközök hadseregszintű tároló, ellátó, javító feladatainak biztosítására, központi bázisokat hoztak létre. A két háború között a Magyar Királyi Honvédség gépjármütechnikai ellátását a Magyar Királyi Honvéd Gépkocsi Szertár végezte. A szertár a Honvédelmi Minisztérium Anyagi Föcsoportfőnökének irányítása alatt álló HM 3/b. osztály közvetlen alárendeltségébe tartozott, ${ }^{34}$ és a hadsereg gépjármüvekkel, gépi harceszközökkel, kerékpárokkal és üzemanyaggal való ellátását végezte. 1939-től a Gépkocsi Szertár tevékenységi köre egyre bővült, ezért - mivel a korábbi, Ezredes utcai szűk objektum nem biztosította a megnövekedett feladatok végrehajtását -, a szertár Mátyásföldre költözött át. A második világháború árnyékában, a hadsereg felszerelése érdekében a Mátyásföldön működő Magyar Általános Gépgyár területét a honvédség vette igénybe. A gyár katonai parancsnokot kapott, és a kapu fölé felkerült a Magyar Királyi Honvéd Gépkocsi Szertár felirat. Erről tanúskodnak Lissák Tivadar tartalékos föhadnagy fényképfelvételei is a Fortepan fotóarchívumban. (A mátyásföldi

33 Varga József visszaemlékezése: http://tanulovezeto.eu/node/543

34 Leskó Zsigmond: Bemutatkozik az MH Logisztikai Ellátó Központ Katonai Logisztika 2009/2.sz. 161-173.o. 
Gépkocsiszertár történetét Varga Imre, a HM Hadtörténeti Intézet és Múzeum levéltárosa dolgozta fel nagy részletességgel a Katonai Logisztika folyóiratban. ${ }^{35}$ )

A szertárat Mátyásföldön nem ürítették ki teljesen, így nem is költözött ki 1944-ben. 1945 tavaszától a szovjet haderő rendezkedett be a szertár épületeibe. A Mátyásföldön tárolt gépi és szerszámanyagot sem szerelték le a kiürítéskor, illetve nem rombolták szét, sőt, tovább használták. 1945 tavaszától a mühely tovább müködött, először szovjet katonai ellenőrzéssel, később önálló magyar honvédségi alakulatként. Azonban a magyar gépjármüves szervezet mindvégig ott volt 1945 után is. ${ }^{36}$

1945. április 17-én Buda magyar parancsnoka Oltay Károly alezredest bízza meg a Gépkocsi Javító Mühely és Honvéd Gépkocsi Szertár $^{37}$ vezetésével. Erre a napra vezeti vissza az MH Anyagellátó Raktárbázis, mint katonai szervezet történetét, és így az egykori jogelőd megalakulásának évfordulója lett csapatünnepének dátuma is. Fő feladatuk a helyreállítási munkák elvégzésén túl a háborút túlélt, használható gépjárművek begyűjtése volt. „A begyűjtést két gyűjtőállomásra szervezték, egy budai és egy pesti állomásra... illetve üzembe helyezték visszaköltözés után az Ezredes utcai karbantartó állomást." ${ }^{38}$ Két gyűjtőpont volt tehát, az egyik Pesten (ez volt Mátyásföld, a Gépjármüszertár bázisa, hiszen a javítandó repülőgépeket is itt gyűjtötték, de eleve itt gyüjtötték a javításra váró gépjármütechnikai eszközöket 1939-1945 között is) a másik pedig Budán (ez volt a Vérmező - amihez közel volt a korábbi gépjármütechnikai bázis az Ezredes utcában). Ekkor helyezték üzembe ismét - a mátyásföldi gépjárműszertár mellett - a jóval kisebb Ezredes utcai bázist is. ${ }^{39}$

1946-tól Budán fokozatosan megszűnt a gyűjtőpont (Vérmező). 1948. október 01-én az Ezredes utcai szertár megmaradt állományával ismét Mátyásföldre költözött. ${ }^{40}$ Hamarosan hozzákezdtek a ma is

Varga Imre: Adalékok az MH Anyagellátó Raktárbázis történetéhez - A Gépkocsi Szertár I. - II. rész. Katonai Logisztika 2016. évi II. és 2017. évi 1. szám Uo. II. rész.

37 A honvédelmi miniszter 5858/Gk.oszt. számú rendelete Csapattörténeti könyv Fnyt: 44/1959. 1.o.

38 Dr. Gáspár Tibor: Adalékok A Magyar Honvédség Logisztikai Ellátó Központ történetéhez I. rész Katonai Logisztika 2015. évi 1. sz.

39 Uo.

40 Az Ezredes utcai bázis ismét (1939 óta másodszor) bevonult az ezalatt folyamatosan üzemelő Mátyásföldre. 
álló raktárépületek felépítéséhez a volt MÁG gyár és repülőtér területének délnyugati szélén. A zömmel ma is álló raktárépületek 1950-töl fogva több mint egy évtizeden át épültek.

$A z$ intézet feladata volt a beérkező új jármütípusok átvétele és csapatpróbája. Megszervezték a technikai kiszolgálások rendszerét, a teljesített kilométer alapján történő rendszeres ellenőrzést. 1951ben megváltozott az anyagkiadás rendje, bevezetésre kerül a negyedéves anyagigénylési rendszer. Az igények összeállításához normafüzet került kiadásra. 1956 őszéig a csapatok gépjármütechnikai eszközeinek szakanyaggal történő ellátása a megszokott rendben folyt. 1957 tavaszán az intézet megnevezése Központi Páncélos- és Gépjármü Anyagraktár (MN 9595) lett. ${ }^{41}$ 1983. augusztus 01-én megalakult a Páncélos- és Gépjármütechnikai Ellátó Központ, amely szervezetileg a Páncélos- és Gépjármütechnikai Szolgálatfönökség közvetlen alárendeltségébe tartozott. Feladata kezdetben a Magyar Néphadsereg, későbbiekben a Magyar Honvédség páncélosés gépjármütechnikai eszközökkel és fenntartási anyagokkal történő ellátása volt.

A régi MÁG gyárépület hasznosítása a megváltozott helyzethez igazodott. Az Autófenntartó Ipari Tröszt (AFIT) levéltárban fennmaradt iratok alapján ismert, hogy egy 1957-es KPM rendelet alapján megalakult a KPM Autófenntartó Ipari Tröszt az autófenntartó ipari, továbbá autó- és alkatrészkereskedelmi, valamint autóközlekedési építő és tatarozó vállalatok irányítására. A gépjárműjavítás államszocialista története szempontjából fontos AFIT központja 1963-tól a Váci út 45. szám alatt települt. A tröszt vállalatai között találjuk a fennmaradt dokumentumok és az Újszász utcai MÁG épület homlokzatán máig látható felirat szerint a VI. sz. Autójavító Vállalatot és annak 3. számú üzemegységét is - ekkor még Budapest XVI. Mátyásföld Keresztúri út 1-3. címmel. ${ }^{42}$

\subsection{Repülö-logisztikai szervezetek a II. világháború után}

1945 után a HM próbálta begyűjteni azt a sérült repülőgépanyagot, amely a szovjet csapatok zsákmányolása után félreeső helyeken még megtalálható volt. A mátyásföldi anyagraktárba gyűjtötte

41 Harci hagyományok, az egység története Fnyt: 44/1959.

42 Négyesi Pál: AFIT, autószervizek Magyarországon 1945-1990 www.magyarjarmu.hu 2015. február 
össze mindazt, amit talált. Ekkor még volt kilátás Bü $131 \mathrm{D}$ és Arado 96 típusok újjáépítésére, mivel a Dunai Repülőgépgyár Rt. javítási lehetőségei megvoltak, bár gyártani már nem volt képes. 1946. június 22-én a Szövetséges Ellenőrző Bizottság (SZEB) jóváhagyásával kiadott szervezési intézkedés értelmében a 34 fővel működő Légügyi Osztály megszünt, feladatait az Anyagi Főcsoportfőnökség alárendeltségébe tartozó Anyagellenőrző Osztály vette át. Ismert egy 1946 nyarán készült fényképfelvétel, mely a mátyásföldi anyagraktár romos csarnokában készült. Ezen jól felismerhető 3 db Me 109 (W.O+08-as G-14; a V 8+12 jelü Ga-6, a harmadik nem azonosítható), amelyeket motorral együtt szállítottak be. Továbbá $2 \mathrm{db}$ Ar 96 és több Bü 131 gép törzsrészei is láthatók. A szárnyakat leszerelve, fatámaszték között a belépőélre állítva tárolták. Ahogy fentebb említettük, végül egyet sem javítottak ki, majd 1947-ben ezeket feldarabolták. ${ }^{43}$

1947. szeptember 16-án az Országgyűlés ratifikálta a Békeszerződést, ezzel egyidejüleg megszünt a SZEB tevékenysége hazánkban. A II. világháború után, 1947. december 1-én, mint a logisztika korai képviselője, a mátyásföldi repülötéren megalakult az 1 . Honvéd Repülőtér Gondnokság és a Honvéd Repülőgép-javító Műhely, valamint itt alakult meg az újjászerveződő katonai repülés első alakulata: az 1. Önálló Repülőszázad is. 1948-ban Mátyásföldön kezdték meg a gyakorló repüléseket Bücker Bü-131 kétfedeles iskolagépekkel.

A Honvédelmi Minisztérium Haditechnikai Intézetében (HM HTI) a repülőműszaki feladatokat a III. alosztályba tartozó Horváth Kálmán mérnök őrnagy és további három hajózó beosztású tiszt látta el. A Repülő Kísérleti Állomás (RKÁ) 1948 júniusában alakult meg Mátyásföldön, és a HM HTI részére különleges repüléstechnikai kísérleteket, repülőgép-berepüléseket, repülöanyagok szabványosításával kapcsolatos ügyek intézését, motorvizsgálatok végzését, atrapbombák készítését végezte. ${ }^{44} \mathrm{Az}$ állomás létszáma 35 tiszt, 15 tiszthelyettes és 5 írnok volt. Az állomást az Intézet hatásköréből 1950 januárjában vonták ki, állományát átadták a Tököl-Szilágytelepen működő Repülő Műszaki Intézetnek (REMI), mely 1951. október 1étől 1957-ig MN Repülőgép és Motorjavító Mühely néven müködött.

43

44

Sárhidai Gyula: Az utolsó Messerschmittek Magyarországon

Dr. Hajdú Ferenc-Sárhidai Gyula: A Magyar Királyi Haditechnikai Intézettől a HM Technológiai Hivatalig HM TH Budapest, 2005. 
Ugyancsak 1948 áprilisában alakult meg Mátyásföldön a Katonai Átvételi Intézet Tokay Imre főhadnagy parancsnokságával, 2 fő hajózó és 6 fő müszaki tiszttel, amely intézet feladatai közé tartozott a különböző gyárakban folyó javító, karbantartó és felújító munka koordinálása, ellenőrzése, az elkészült repülőgépek átvétele és berepülésre történő előkészítése. A szervezet 1953-tól beolvadt a Légierő Központi Repülömüszaki Raktárába. ${ }^{45}$ A kijavított gépek száma 1948 májusára 5 db-ra nőtt.

Az 1948-ban, a Zöld László őrnagy parancsnoksága alatt álló Repülőtér Gondnokság alárendeltségében, Repülőgép javító mühely és Szertár néven létrehozott szervezet kezdetben egyetlen raktárépületben kezdte meg müködését, Mátyásföld repülöterén. A személyi állományt 4 tiszt, 8 tiszthelyettes és 119 legénységi állományú személy alkotta. Elhelyezésük a mai Újszász u. 45. szám alatt álló, lakóépületként funkcionáló laktanyában volt. Megkezdődött az elszenvedett háborús károk elhárítása, a romok eltakarítása, majd a Szertár jellegéből adódó feladatok: javítások végrehajtása, repülő szakanyagok tárolása és a csapatok szakanyagokkal történő ellátásának végrehajtása. $A$ szervezet két részből állt. $A$ javítómühely parancsnoka Kenéz Endre őrnagy, a szertár parancsnoka Dajka Miklós őrnagy volt. A II. Világháborút követő első repülőműszaki katonai logisztikai szervezet hivatalos megalakítása a Hadtörténeti Intézet és Múzeumban található okmány alapján 1949. március 16 -ra tehető. ${ }^{46}$ Az ugyancsak ekkor létrejött Repülöcsapatok Parancsnoksága alárendeltségében lévő Szertár parancsnoka 1949-ben Zsolnai Dénes százados lett. A szervezet rendszeresített létszáma 100 fő lett.

Az 1948. július 2-án a Szovjetunióval aláírt katonai segélyegyezmény keretében 1949 szeptembere folyamán 35 db UT-2 típusú repülőgépet adtak át Mátyásföldön. A típus ucsebno-trenyirovocsnij, azaz kiképzés céljára a szovjet Jakovlev tervezőirodában (OKB-115) kifejlesztett, egyenes szárnyú, egymotoros kiképző repülőgép volt.

A vezetés szervezeti változásait lekövetve, ebben az időben gyakran változott a Szertár elnevezése és felépítése is. 1950. májusában a Repülőgép javító mühely és Szertár szervezete kettévált, a javítómühely Székesfehérvárra települt, és polgári igazgatás alatt Repülő

45 Dr. Seres György: A "legnagyobb" magyar légierő 1948-1957

http://drseres.com/maszarny/194957.html

46 HM HIM 711-10099/49 Eln. okm. (A Honvéd Repülő Szertár a „Klapka” szervezéssel, a HM 8000/Eln. HVK. 5/a-49. számú rendelettel került megalapításra) 
Motorjavító N.V. néven müködött. A Mátyásföldön maradt rész a Repülő Szertár elnevezést és az 5435 fedőszámot kapta, ekkor alakultak meg a tároló osztályok is. 1950. június 7-től a Honvéd Légierő Parancsnokságon Repülő Mérnök-Müszaki Csoportfőnökséget szerveztek. A Hadtáp Csoportfönök alárendeltségében 16 fővel megalakításra került a Repülő Müszaki Ellátó Osztály. 1950 őszén az intézet már mint Központi Repülő Müszaki Anyagraktár végezte tevékenységét Szabó András százados parancsnoksága alatt. Az ellátási körbe tartozó alkatrészek az II-10, Li-2, Jak-9P, Arado-96 és a Zlin361 típusokhoz tartoztak. Egy bomba- és lőszerraktár is megalakult 1950-ben Mátyásföldön, a Légvédelmi Parancsnokság alárendeltségében. ${ }^{47}$

1951-től a Szertár jelentős szerepet kapott a beérkező új, szovjet repülőtechnika átvételében és a repülőcsapatokhoz történő eljuttatásában. 1951. március 16-án a magyar légierő új korszakba lépett a korszerü, sugárhajtású MiG-15 vadászrepülő típus hadrendbe állításával. 1952-től beindult és rendszeressé vált az ejtőernyős kiképzés, 3 év alatt mintegy 200 fő ejtőernyős katona kapott Mátyásföldön kiképzést. A tárolási gondok megoldásaként a mátyásföldi ejtőernyőraktár teljes anyagát átköltöztették a táci ejtőernyőraktárba.

A mátyásföldi Központi Repülő Műszaki Anyagraktár a szovjet csapatok megjelenéséig müködött, bár 1956 nyarán az elöljáró parancsnokság utasítást adott az Anyagraktár Székesfehérvárra történő áttelepítésére, mely $70 \%$-ban meg is valósult. A zürzavaros politikai helyzet miatt a parancsot végül visszavonták. A forradalmi események során a hivatásos állomány a pesterzsébeti rendőrséggel közösen járörözve biztosította az IKARUS gyár és a XVI. kerületi gabonaraktár őrzését. Az 1956 novemberében hazánkba nyomuló alakulatokból létrejött a Déli Hadseregcsoport (JuGeVe, azaz Juzsnaja Gruppa Vojszk, amelynek hivatalos „alapító okmányát” csak 1957ben írták alá), és az alárendeltségében lévő 59. Légi Hadsereg törzse Mátyásföldön került elhelyezésre. 1956 után a szovjet haderő repülöparancsnoksága települt a mátyásföldi objektumban, illetve üzemeltette a füves repülöteret 1990-ig.

1957 tavaszán Vági Andor ezredest nevezték ki a Raktár parancsnokának. 1957-58 között a Hadtápfönökség szervezetében Müszaki

47 Dr. Gáspár Tibor: Fejezetek a Fegyverzeti Szolgálat és jogelődei történetéből IV. rész 
Ellátó Szolgálat alakult, melynek állománya: 6 fő repülőmüszaki raktáros, 6 fő oxigéntöltő, 8 fö légsürítőállomás-kezelő, 8 fő akkumulátortöltő-állomás kezelő, 15 fő fegyverraktáros és egy 12 fős üzemanyagrészleg. 1958-ban jelent meg az inkurrencia-kezelés feladata a Raktár fö tevékenységei között. Az új repülötechnikai eszközök és anyagok fogadása szükségessé tette az elöregedett és feleslegessé vált repülőműszaki szakanyagok leválogatását. 1961 júliusáig mintegy 640 vagon anyag került átadásra a népgazdaság számára, mellyel javult az amúgy is szűkös tárolótér felhasználásának helyzete. 19611967 között a szervezet parancsnokává Ángyás László ezredest nevezték ki.

A hidegháborús években napirenden voltak a kitelepítési gyakorlások. A Raktár állománya többször hajtott végre szakanyag-kitelepítést a Gánti Tábor területére (1963-ban 4 alkalommal), és ilyen esetekben onnan szervezte a szakanyagellátást is. Ebben az időszakban került bevezetésre a korszerü szemléletü készletgazdálkodás és a minimum-maximum készletek megállapítása is. Ez idő alatt az alakulat két szervezeti elemmel, a honi légvédelmi tüzértechnikai részleggel és a központi rádiótechnikai anyagraktárral bővült. ${ }^{48}$

1966-ban újabb szervezési intézkedések folytán az Anyagraktár új megnevezése Országos Légvédelmi Parancsnokság Szertár lett. 1967. január 10. és február 25. közötti időszakra tehető, amikor az Országos Légvédelmi Parancsnokság Szertár és a szállító zászlóalj áttelepült Isaszeg helyőrségbe. A Szertár az MN 1678 hadrendi számot kapta. Elkezdődött az isaszegi laktanya fejlesztése, új tárolóhelyiségek létrehozása, legénységi körlet, parancsnoki épület, étkezde építése. A kiürített mátyásföldi épületek további hasznosításra átadásra kerültek az IKARUS Vállalat részére.

1967-2013 között a repülőmüszaki szakanyagellátás az isaszegi laktanyából történt, de az MH Haditechnikai Ellátóközpont megalakulásával létrehozott Üzembentartást és Anyagellátást Tervező Részleg a raktár feletti szakmai felügyeletet Mátyásföldröl látta el. 2009-ben az évek óta tervezett, Mátyásföldre történő diszlokáció tervezési munkái már folyamatban voltak. ${ }^{49}$ 2013. 06. 23-án az MH Logisztikai

48

49

MH 5435 alakulatának története kézirat Fnyt: 105/1959 és A Központi Repülö Anyagraktár története kézirat Fnyt: 399/1986

Leiner László: Az MH Logisztikai Ellátó Központ 1. Raktárbázis Repülőműszaki Anyagraktár és jogelőd szervezetei fennállásának 60. évfordulója alkalmából mondott beszéde (kézirat 2009.03.14.) 
Ellátó Központ (Budapest) és az MH Veszélyesanyag Ellátóközpont (Pusztavacs) összevonásával létrejött az MH Anyagellátó Raktárbázis Nagy Attila ezredes parancsnokságával, az ugyancsak ekkor létrehozott MH Logisztikai Központ közvetlen irányítása alatt. 2013. 11. 01 -én befejeződött az isaszegi laktanya teljes kiürítése.

A Repülőmüszaki Anyagraktár munkáját a továbbiakban végletekig leegyszerüsített struktúrában Antal Imre mk. százados parancsnoksága alatt folytatta tovább az $\mathrm{MH} A R B$ mátyásföldi telephelyén. $A z$ eredeti, történelmi helyszíntől nem messze, az Újszász u. 37-39. szám alatti objektum 16. sz. épületében és a tárolásra szolgáló 4-es csarnokban folytatódott a raktározási munka. $\mathrm{Az} \mathrm{MH}$ által üzemeltetett típusok drasztikus csökkenésével a tárolt anyagok mennyisége is jelentősen csökkent, az inkurrenssé vált szakanyagok mértéke pedig megnövekedett.

\subsection{A közelmúlt katonai logisztikai szervezeteinek fejlödése}

2000. november 01 -én a NATO konformitás, valamint a takarékosság jegyében a korábbi haditechnikai eszközök ellátására szakosodott önálló ellátó központok megszűntek. Jogutódjukként, mátyásföldi központtal megalakult a Magyar Honvédség Haditechnikai Ellátó Központ, mely vezető szerve lett az alábbi, önállóságukat vesztett, korábbi ellátó központoknak:

- MH Páncélos- és Gépjármütechnikai Ellátó Központ, később Lánctalpas és Hőerőgép Raktár (Budapest, Mátyásföld);

- MH Repülőanyag Ellátó Központ (Isaszeg);

- MH Tápió Fegyverzettechnikai Ellátó Központ (Tápiószecső);

- MH Elektronikai Anyagi Technikai Ellátó Központ (Nyíregyháza);

- MH Müszaki Technikai Ellátó Központ (Budafok-Háros);

- MH Vegyivédelmi Ellátó Központ (Budapest-Jászberényi út);

- Rakétatechnikai Ellátó Központ (Nyírtelek);

- Híradó Anyag Ellátó Központ (Gödöllö);

- MH Kiképzéstechnikai Ellátó Központ (Esztergom);

- MH 1. Kijelölt Állandó Raktár (Kalocsa). 
A Virág Lajos mk. ezredes parancsnoksága alatt álló MH HTEK feladatait az MH Összhaderőnemi Támogató Parancsnokság (Budapest) szolgálati alárendeltségében és szakmai irányítása mellett végezte. A haditechnikai integrációval párhuzamos folyamatok zajlottak a hadtáp területeken is, hiszen az MH Hadtáp-anyag Ellátó Központ szervezete a korábbi MH Üzemanyag Ellátó Központ, MH Ruházati Ellátó Központ, MH Élelmezés Ellátó Központ, MH Humán Anyagi Alosztály, MH Térképészeti Anyagellátó Alosztály összevonásával jött létre.

2007. március elsejével a logisztikai integráció által megkövetelt további szervezeti változás következtében a Haditechnikai Ellátó Központ és a Hadtápanyag Ellátó Központ, mint költségvetési szervezetek megszűntek, és a Magyar Köztársaság Honvédelmi Minisztere határozatában új, ezredszintű költségvetési szervet alapított Mátyásföldön: létrejött a Logisztikai Ellátó Központ Barnucz Albert okl. mk. ezredes parancsnokságával. ${ }^{50}$

Az MH LEK működőképességét 2007. augusztus 31-re érte el. Az új szervezet feladatait az MH Összhaderőnemi Parancsnokság (Székesfehérvár) szolgálati alárendeltségében, a HM Fejlesztési és Logisztikai Ügynökség szakmai irányítása mellett végezte.

Fő feladata a Honvédelmi Minisztérium háttérintézményeinek, valamint a Magyar Honvédség szervezeteinek teljes körü, végrehajtó szintü logisztikai biztosítása volt. Az MH LEK végezte a Magyar Honvédség katonai szervezeteinek ellátását a hatáskörébe tartozó előírt szakanyagokkal. Az MH ÖHP által meghatározott szakanyagok beszerzését (köz)beszerzési eljárásokban valósította meg. Feladata volt a központi beszerzésű szakanyagok végátvétele és azok előírás szerinti tárolása, karbantartása.

Külön rendelkezések alapján végezte a különféle NATO és nemzetközi missziók ellátásával kapcsolatos szakmai feladatokat. Forgalomba helyezte az MH gépjármüveit, hatósági okmányokkal és jelzéssel látta el őket. Szervezte a gépjármüvek, erőgépek, repülőeszközök, egyéb szakanyagok javíttatását. Az MH személyi állományának ellátására Katonai Ruházati Ellátó pontokat működtetett.

50 Intézkedések: 9/2007 (HK 4.), 15/2007 (HK 4.), 25/2007 (HK 4.) 
A központi logisztikai támogatás a szakági Üzembentartást és Anyagellátást Tervező Részlegek szakmai irányításával történt, melyek a vonatkozó szabályzók feszes betartásával, a mindenkori érvényes Logisztikai Utaltsági Rendben szereplő lépcsőzéssel végezték a katonai szervezetek szakanyagokkal és eszközökkel történő ellátását. A Logisztikai Ellátó Központ feladatait 5 zászlóalj-szintű raktárbázissal, egy kijelölt állandó raktárral és öt inkurrencia-tároló raktárral látta el, mely szervezetek az ország területén több mint 14 helyőrségben helyezkedtek el. A személyi állomány többségében korszerű irodákban, munkahelyeken dolgozott, azonban a régi raktárak állaga már nem minden esetben felelt meg a kor követelményeinek. A személyi állomány jól felkészült szakemberekből állt, akik tudásukat az önképzések, illetve a továbbképzések alkalmával folyamatosan bővítették.

2013. 06. 23-án az MH Logisztikai Ellátó Központ (Budapest) és az MH Veszélyesanyag Ellátóközpont (Pusztavacs) összevonásával létrejött az MH Anyagellátó Raktárbázis Nagy Attila ezredes parancsnokságával, az ugyancsak ekkor létrehozott MH Logisztikai Központ közvetlen irányítása alatt. A logisztikai integráció, az új korszak kihívásainak jobban megfelelni képes szervezet szakmai irányítása Baráth István dandártábornok nevével fémjelezhető Logisztikai Központra hárult.

A haderő korszerüsítése során elindult folyamat befejezéseként a jelenlegi ellátó központok összevonásával a közeljövőben egy centralizált „Központi Logisztikai Bázis” kialakulása körvonalazódik. A tervek között szerepel egy eszközkövető rendszer bevezetése, illetve a vonalkódos leolvasórendszer alkalmazási körének kiszélesítése is.

Mindezek megvalósulása elsősorban az elöljárói döntéstöl, leginkább pedig a rendelkezésre álló költségvetési keret nagyságától függ. ${ }^{51}$

51 Kaposvári László: Az MH logisztikai rendszerének fejlesztési irányai konferencia előadás Budapest 2013.

Boczák Attila: A logisztikai támogatási rendszer korszerüsítésének lehetőségei, Honvédségi Szemle 2011 6. sz. 10-11.o.

Baráth István: Az MH logisztikai rendszerének aktuális helyzete konferencia előadás Budapest 2013.

Baranyi Ferenc - Lengyel András: Gondolatok a KLB-ről Katonai Logisztika 2003/4 szám. 68-83.o. 


\section{A korszak emlékművei Mátyásföldön}

\subsection{Gépkocsizók hősi emlékmüve (oroszlán)}

Lissák Tivadar remekbe szabott fotósorozatában (Fortepan fotóarchívum) látható a korábbi MÁG főépületének Újszász utcai oldalán, egy dombra épített, díszfallal körülvett, bronz koszorúval ékesített, magas talapzaton álló emlékmü 1943-ban a Magyar Királyi Honvéd Gépkocsiszertár területén, melynek lábazatán „A Hazáért” felirat olvasható. A talapzaton egy mükőből öntött oroszlánszobor állt. A szobor sorsa annak ellenére talányos, hogy eredeti felállítási helyétől nem messze, máig látható. Prohászka László Szoborsorsok ${ }^{52}$ című könyvében alkotóként Maugsch Gyulát említi 1928-ból. Felállítási helyként az Ezredes utcai gépjármüves laktanyát valószínüsíti. (Innen költözött át a gépkocsizó-müszaki szakterület javítóbázisa 1933-1939 között Mátyásföldre, az októberben megalapított Magyar Királyi Honvéd Gépkocsiszertárba.) A laktanyának két kapuja volt, a másik a Káplár utca felé nyílt, ott állhatott az emlékmü. Alkotóként felmerülhet Seenger Béla kőfaragó neve is a Nemzeti újság képes mümelléklete ${ }^{53}$ alapján. Az oroszlán az Országos Kézmúvesipari Tárlat Mestercsarnokában Seenger Béla kőfaragó csarnokában volt kiállítva 1928-ban, majd felavatták a Városmajor mellett a Káplár utcai honvédgarázs előtt, az l. Világháborúban hősi halált halt gépkocsivezetők emlékére. A szálak tehát összefutni látszanak, de az alkotó kiléte homályban marad. Rajna György Budapest köztéri szobrainak katalógusa ${ }^{54}$ címü könyvében a Gépkocsivezetők első világháborús emlékműve alkotójaként Mausch Gyulát említi. A felállítás évét 1934-re teszi, szintén a II. ker. Ezredes u. 5. szám alatti laktanyába. Közli viszont, hogy a szobor elpusztult. Ismert tény, hogy 1945 után, számos első világháborús emlékmúvet eltávolítottak a laktanyákból, az Ezredes utcából a Gépkocsizók hősi emlékét (Maugsch Gyula alkotását) is.

A XIV. kerületi Czázár András utca 5. szám alatt egykor Rákos Manó szobrász müterme és lakása állt. A ház előtti, az utcáról is könnyen észre vehető oroszlánszobor, bár talpazatán nincs felirat,

52 Prohászka László: Szoborsorsok Kornétás Kiadó, 1994

1928. szeptember 16. szám

54 Rajna György Budapest köztéri szobrainak katalógusa Kiadó: Budapesti Városvédő Egyesület 1989. 
mindenben megegyezik a mátyásföldivel. A jelenlegi bérház lakói Rákos Manó épületszobrásznak tulajdonítják az alkotást.

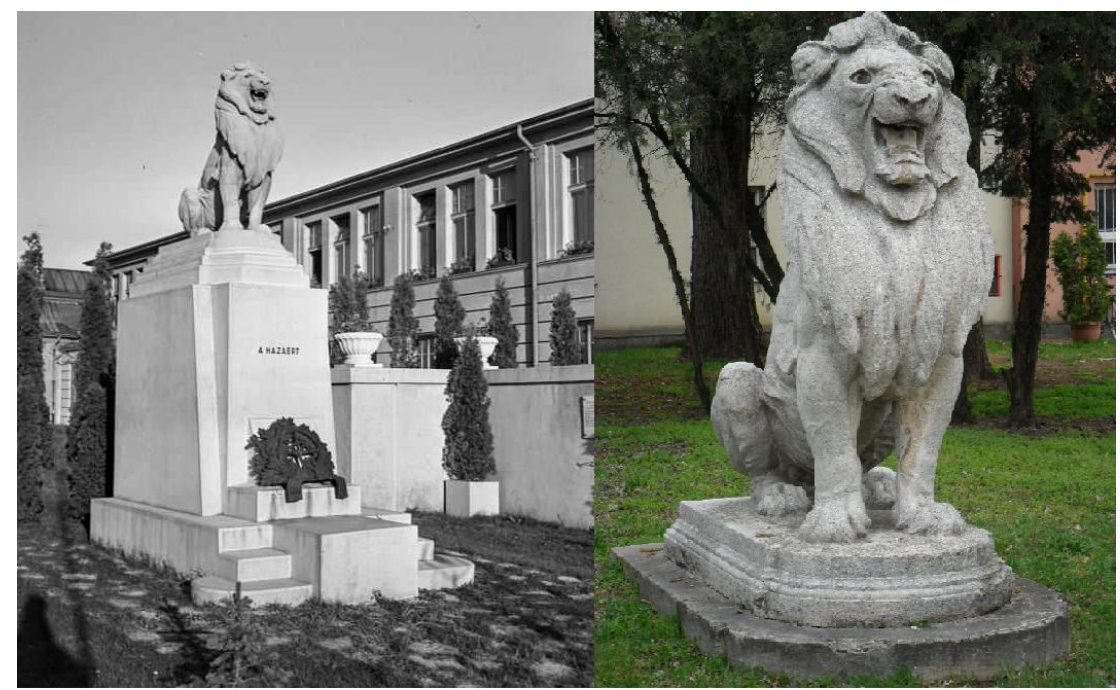

16. számú ábra. Az I. világháborús gépkocsizók hősi emlékmüve 1943-ban a M. Kir. Honvéd Gépjárműszertárban és ma az MH ARB területén

A mátyásföldön települő MH Páncélos- és Gépjárműtechnikai Ellátóközpont utolsó parancsnoka - aki az oroszlán szobrot a MÁG főépület elhanyagolt kertjéből mostani helyére, az Újszász utca 58. szám alatti objektum udvarára menekítette - információja szerint azt maga Horthy Miklós kormányzó úr ajándékozta a reptérnek ${ }^{55}$. A szobron sem véset, sem felirat nem látható.

\subsection{A MÁG torony emléktáblája a kapunál}

Az Újszász utca 41-43. szám alatti egykori MÁG főépület utcai főhomlokzatán, a négy árkádnyílás két oldalán valaha két emléktáblát helyeztek el. Lissák Tivadar fényképein jól látható a két, egyforma kivitelü I. Világháborús márvány emléktábla. Mindkét oldalon azonos kiképzésben, a táblákat falba épített kő virágláda díszíti. A virágláda alatt a magyar királyi címerpajzs látható - a háborúra utaló - tölgyfa ágakkal körülvéve, fölötte a magyar királyi Honvéd Gépkocsiszertár emblémája, a kormánykerék szárnyakkal és örökmécses látható.

55 Izbéki János nyugállományú alezredes szóbeli közlése 2011. 


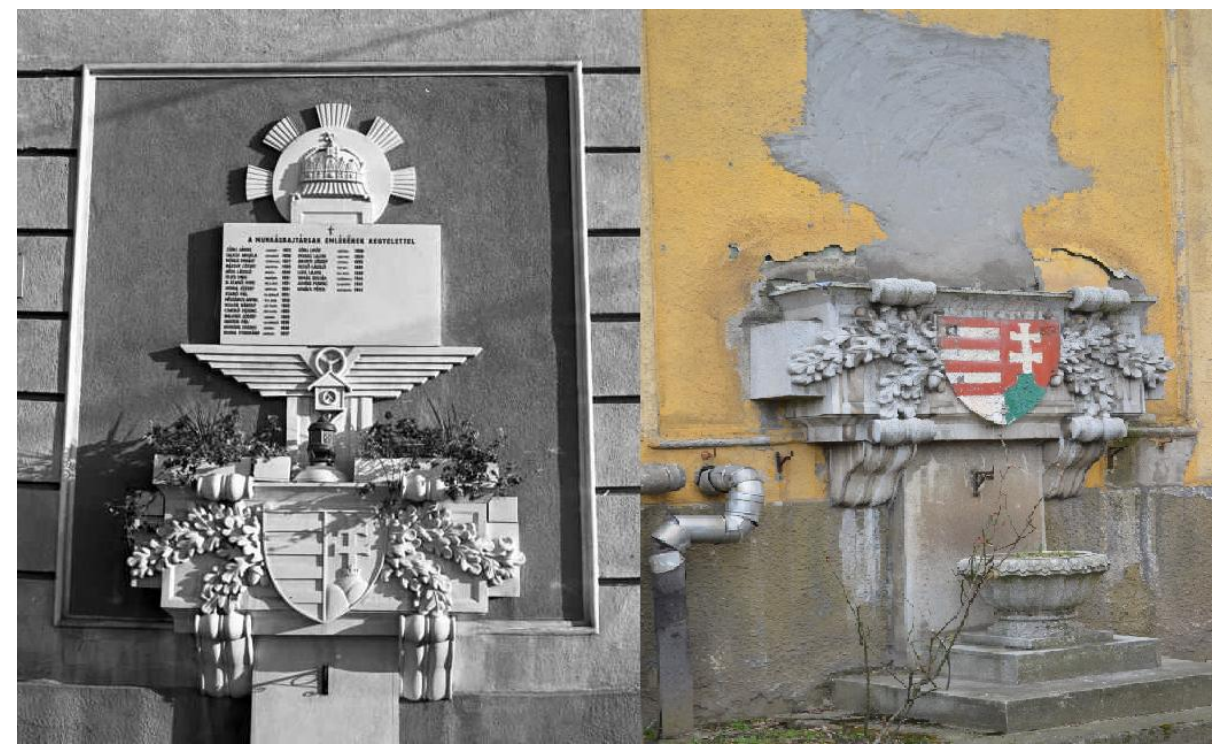

17. ábra. Az I. világháborús „Munkabajtársak emléktáblája” a Magyar Királyi Honvéd Gépkocsiszertár emblémájával régen és ma a MÁG föépületen

A tábla fölött, a sugarait kibocsájtó napkorongba burkolózó Szentkorona helyezkedik el. A bal oldali tábla felirata sajnos nem látható a felvételeken, a jobb oldali emlékművön viszont 24 név és az alábbi szöveg olvasható: „Munkabajtársak emlékének kegyelettel”. Az évtizedek múltával az épület homlokzatának képe némileg megváltozott. A két szélső árkádnyílást befalazták, a bal oldali emlékmü helyére ablaknyílást vágtak, így az teljesen elpusztult.

A jobb oldali emlékmű részben ma is látható. Az emléktáblát ugyan az utóbbi évtizedben levették, és azóta nincs hír hollétéről, de a magyar királyi címerpajzs a tölgyfaágakkal látható.

\subsection{Dísztó Szent Kristóf szobrával}

Lissák Tivadar engedélyt kapott, hogy fotósorozatban örökítse meg a magyar királyi Honvéd Gépkocsiszertár müködését, épületeit, mühelyeit 1943-ban. A felvételek között találkozhatunk egy ünnepi eseményről, római katolikus szertartású tábori szentmiséről készített képekkel is, melyek feltehetően 1939-ben, az alapító ünnepségen készültek. Több felvételen is látható az a dísztó, mely az egykori MÁG főépület Újszász utcai homlokzata és az utca között épült. 


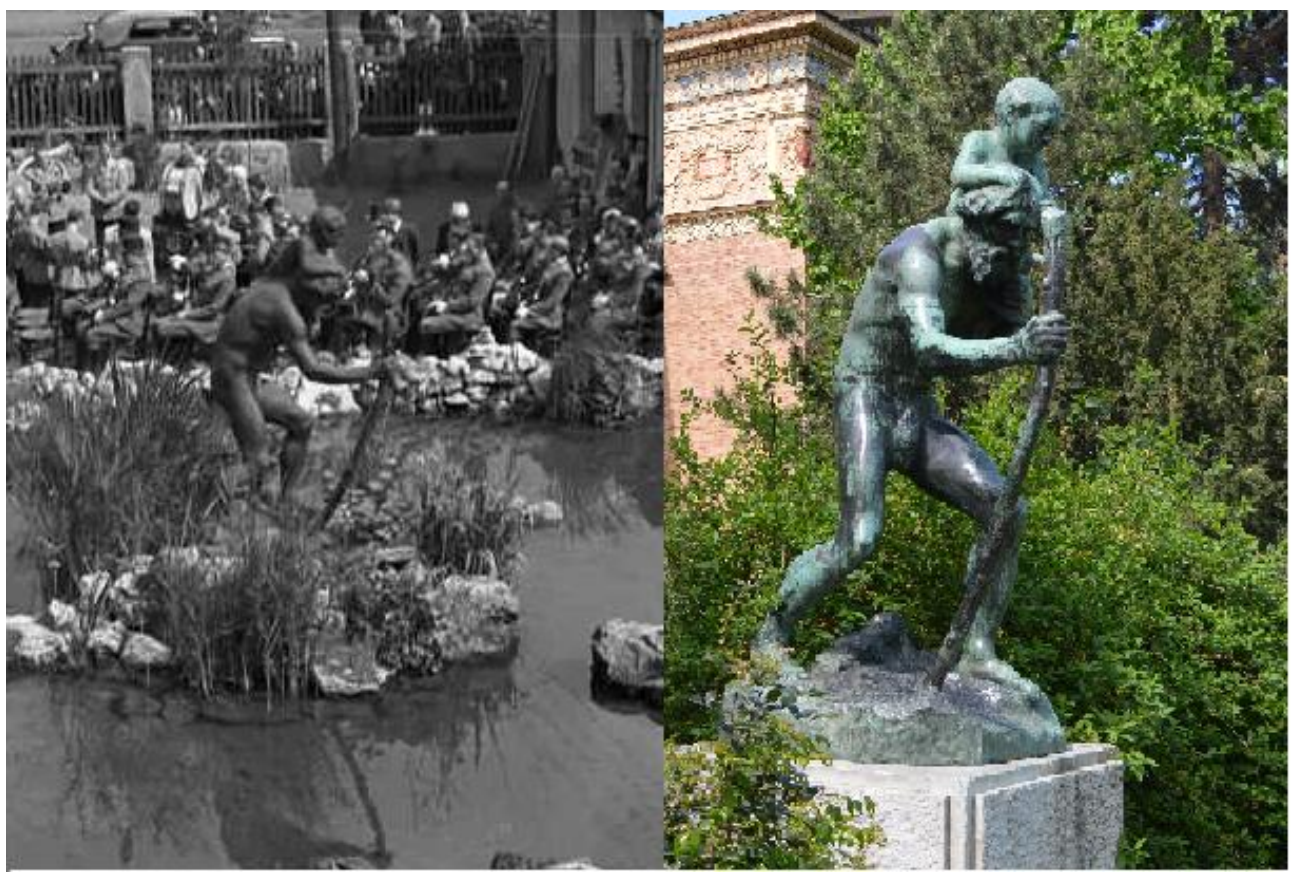

18. ábra. Szent Kristóf szobor (a közlekedők védőszentje) régen a Magyar Királyi Honvéd Gépkocsiszertár emlékparkjában és ma

A mintegy $260 \mathrm{~m}^{2}$ alapterületű 0,3-0,4 méter mélységü tó két részböl, egy magasabban fekvő és egy alacsonyabb víztükrü felületből áll, ívesen záródó „téglány” alaprajzú. A mintegy 0,4 méterrel alacsonyabb tórészbe a hossztengely mentén négyfokú, széles lépcsősor vezet egy mesterséges szigetre. A tóban kisebb sziklák, vízi növények láthatók. A nagyobbik vízfelületben Szent Kristófot ábrázoló fémszobor található

Botfai Hűvös László 1883-ban született, a Képzőművészeti Főiskolán festészetet tanult, csak 1909-ben Rodin tanácsára tért át a szobrászatra. 1910-ben Párizsban készítette a „Szent Kristóf a gyermek Jézussal" címü monumentális szobrát, mely kitűnő kritikát kapott. A múvész 1913-ban tért haza Budapestre. 1948-tól New Yorkban élt, ott is halt meg 1972-ben. Aktív éveiben föként portrékat mintázott. Hűvös László nem túl nagyszámú köztéri alkotása között kiemelkedő jelentőséggel bír a Szent Kristóf-szobor, mely a közlekedők védőszentjét mintázza. 1932-ben a Stefánia útra készült egy másolat carrarai márványból, Szántódra 1939-ben bronzból. A mátyásföldi másolatról nincs ismert irodalmi adat. Ma egy alkotás az Olof Palme sétány elején, a Műjégpálya főbejáratával szemben látható. Sajnos a má- 
tyásföldi Szent Kristóf-szobornak nyoma veszett, a tó azonban jó állapotban ma is látható.

A régi fényképek hátterében felfedezhető az Újszász utca 58. szám alatti katonai objektum máig álló épülete és a ma Veranda Kávézóként üzemelő egykori őrség-épület. A tó közelében máig megtalálhatjuk a fényképeken felfedezhető szép ívű kandeláberek egyikét.

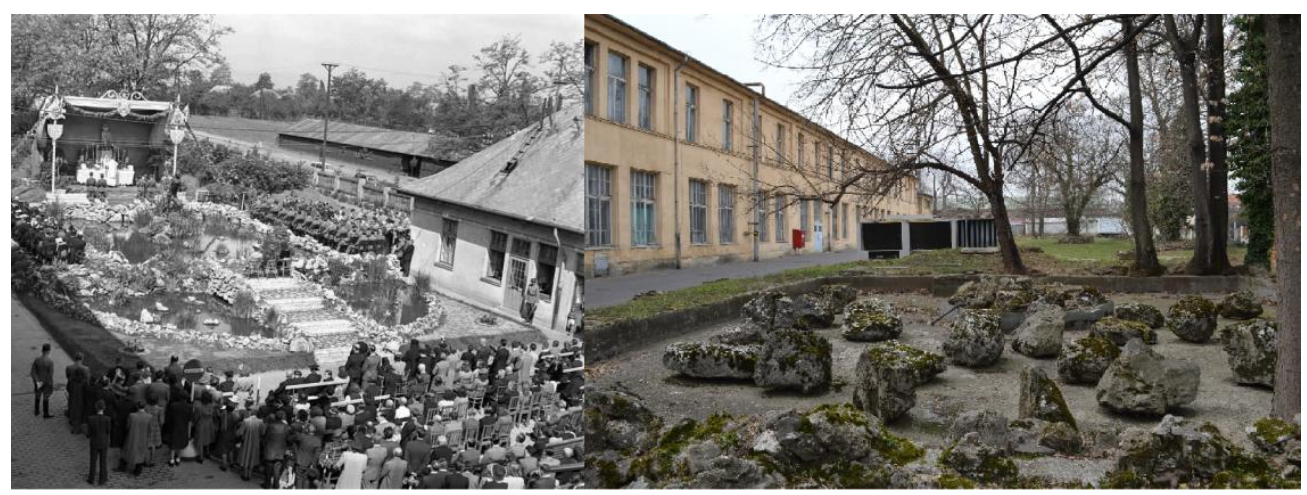

19. számú ábra. Dísztó régen a Magyar Királyi Honvéd Gépkocsiszertár emlékparkjában és ma

\subsection{Corvin Helytörténeti Klub emléktáblája}

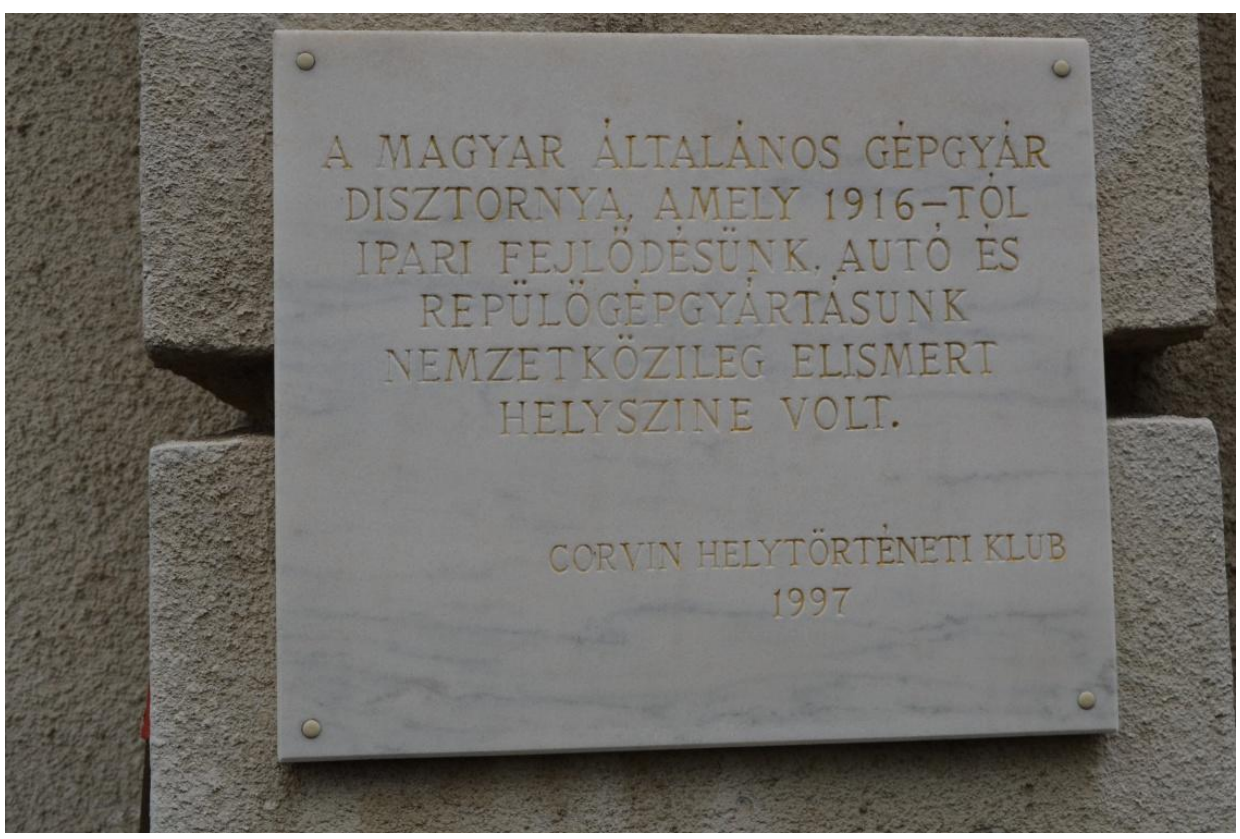

20. számú ábra. A Corvin emléktábla 
Az egykori MÁG főépület Újszász utcai homlokzatán, az árkádos főbejárattól balra, az egykori Gépkocsizók hősi emlékműve (oroszlán) mögött látható az az emléktábla, melyet 1997-ben a Corvin Helytörténeti Klub állított. Az aranybetűs márványtábla felirata: „A Magyar Általános Gépgyár dísztornya, mely 1916-tól ipari fejlődésünk, autó és repülőgépgyártásunk nemzetközileg elismert színhelye volt."

Az emléktábla az utcáról nem látszik és nem is látogatható, mert a MABI-BUS Kft. területén fekszik. A gyár legfontosabb termékei a világszínvonalú és újdonságú Evopro Modulo Medio Electric és Hybrid típusú, kompozit karosszériájú, alternatív hajtású jármúvek.

A régi idők gépjármügyártásának emlékét felelevenítendően, 2015től fémkarosszériás, Modulo $M$ típusú járművek is készülnek Mátyásföldön.

\section{5. Ősrepülő emlékmű a csendőrlaktanyánál}

Az 1996-ban, a mátyásföldi repülötér fennállásának 80 éves évfordulóján állított emlékmü a közforgalmú és katonai repülőtér egykori bejáratánál áll. A Pilóta utcával szemközt, mintegy 4 méter magas, vörös terméskőből rakott gúla tetején szétterjesztett szárnyú stilizált madarat láthatunk. $A z$ emlékmübe süllyesztett márványtáblán az alábbi felirat olvasható: „Első vadászrepülőgép gyárunk és közforgalmi repülőterünk emlékére 1916-1996." Az emlékmü másik oldalán, utólag felerősített, kisebb méretű márványtáblán az alábbi szöveg olvasható: „Hálás szívvel emlékezünk az I. és II. Világháború hős pilótáira"

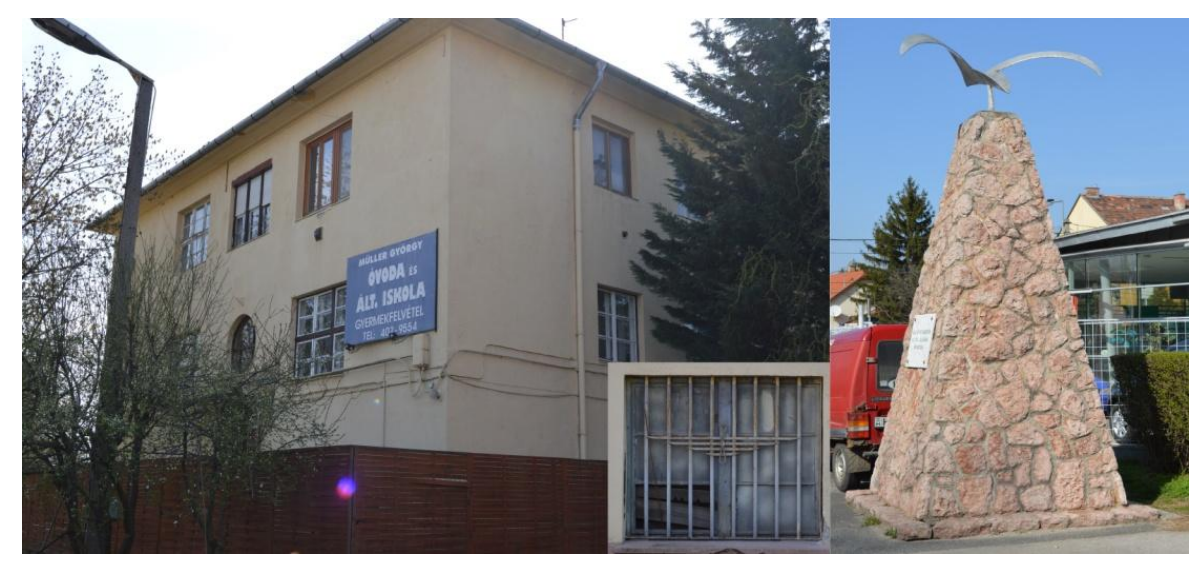

21. számú ábra. Az egykori mátyásföld-repülötéri (légi) csendőrlaktanya épülete és a repülös emlékmü 


\subsection{Prodam emléktábla}

A repülötér közelében, a katolikus templom mögött, a Prodam utca 1. számú ház falán márványtábla állít emléket Prodam Guido fiumei származású, gyógyszerész végzettségü ősrepülönknek, aki 1911. november 4-én először repült Budapest területe felett Horváth III/A típusú monoplánján.

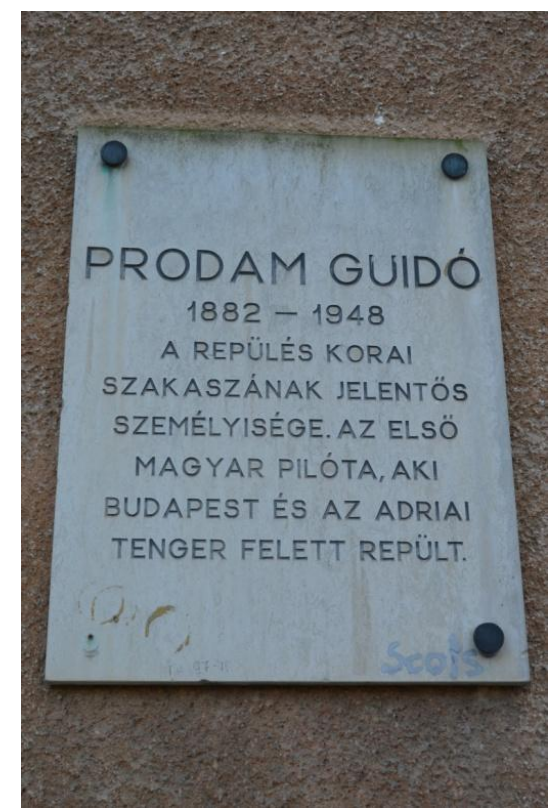

22. számú ábra. Prodam Guido emléktáblája

A márványtábla felirata:" Prodam Guido 1882-1948 A repülés korai szakaszának jelentős személyisége. Az első magyar pilóta, aki Budapest és az Adriai tenger felett repült."

\subsection{Hadtáp katonák emléktáblája}

Az Újszász utca 37-39. szám alatti katonai objektum parancsnoki épülete előtti szépen kialakított parkban áll a 2012-ben a Logisztikusok Napi ünnepség keretében felavatott emlékmü. A szépen kialakított park közepén, téglákból rakott emlékfal és a rajta elhelyezett fekete márványtábla kínál logisztikai katonai emlékhelyet, mely minden valaha élt ellátó katona emlékét őrzi. A Lehel úti nagy múltú hadtáp objektumból áthozott emléktábla felirata: „A Magyar ellátó katonák emlékére. Állította a Magyar Honvédség Anyagitechnikai Föcsoportfönöksége 1996." 


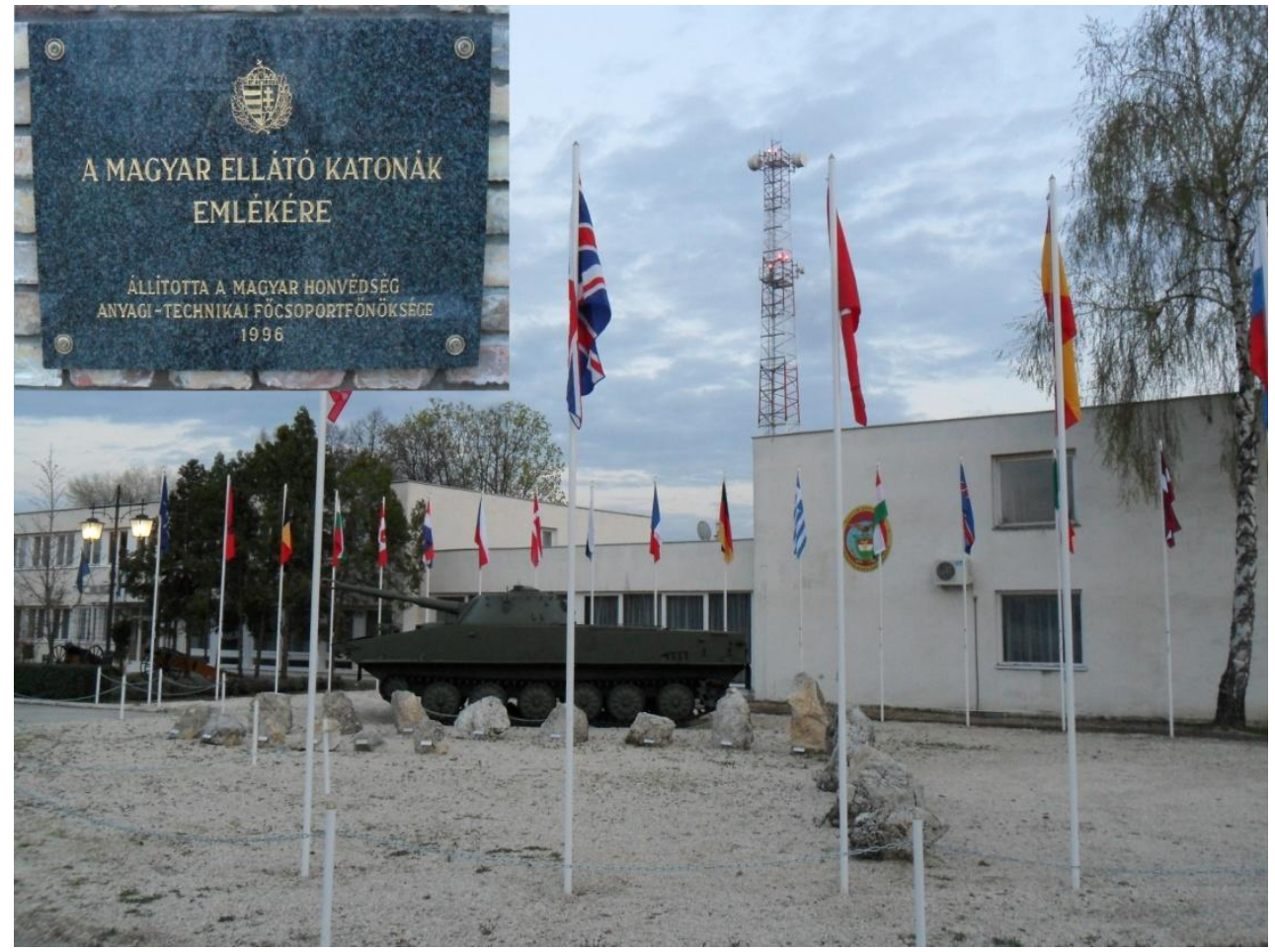

23. ábra. Hadtáp katonák emléktáblája és a logisztikai emlékkő-sor

A Logisztikai Ellátó Központ széttagoltsága, az ország több pontján történő elhelyezkedése miatt a vezető szerveknek is otthont adó mátyásföldi objektumban, a jogelőd szervezeteknek emléket állító emlékkő-sort létesítettek murvával felszórt területen, mely a NATO tagállamok zászlait tartó oszlopok között található. Az emlékművek mellett mini haditechnikai park kialakítására is sor került. A parkban $122 \mathrm{~mm}$ es tarack, 45 mm-es páncéltörő ágyú és ZU-2 légvédelmi géppuska, valamint $2 \mathrm{db}$ mozgókonyha, egy PT-76 felderítő úszó harckocsi és két 1848-as ágyú makettje is látható.

A szerző köszönetet mond Dr. Hegedűs Ernő és Varga Imre urak hasznos tanácsaiért és a szakmai lektorálás feladatainak elvégzéséért.

\section{Irodalom:}

A XVI. kerület története (Minerva, Bp., 1971.) könyv

A MALÉV Repülés- és Üzemtörténeti Kör 1983. évi Konferencia kiadvány 2003. január 
Dr. Abody (Anderlik) Előd: A repülögép és a repülés. Pósa Károly kiadása, (Budapest, 1942.) A magyar repülés centenáriuma Magyar Repüléstörténeti Társaság Bp., 2009.

A Repülő Szertár, Központi Repülő Anyagraktár, MH RAEK, MN PCGTEK, MH LEK csapattörténeti könyvei

Boczák Attila: A logisztikai támogatási rendszer korszerüsítésének lehetőségei, Honvédségi Szemle 2011 6. sz.

Baranyi Ferenc - Lengyel András: Gondolatok a KLB-röl Katonai Logisztika 2003/4 szám. Baráth István: Az MH logisztikai rendszerének aktuális helyzete konferencia előadás Budapest 2013.

Becze Csaba: Kör Ász - egy vadászrepülőszázad története 19361941 Puedlo Kiadó, Budapest é.n.

Czirók Zoltán: A Fokker D.VI-os vadászgép Magyarországon

Corvin Hírnök - Corvin Helytörténeti Klub évkönyvei (1970-1996)

Csanádi-Nagyváradi-Winkler: A magyar repülés története. Műszaki Kiadó Bp. 1977

Dr. Csonkaréti Károly: A császári és királyi légierő. Hajja \& Fiai Könyvkiadó, 2008.

Dalia László: Repülő emberek Sportpropaganda Vállalt 1987.

Endresz István: Fejezetek a hadirepülés történetéből 9. Repülés 1967/3.

Fábián András - Ozsváth Sándor: A magyar tervezésű és gyártású Levente II. kiképző repülögép és légialkalmas másolatának megépítése III. rész Haditechnika 2016/5. szám

Dr. Gáspár Tibor: Adalékok A Magyar Honvédség Logisztikai Ellátó Központ történetéhez I. rész Katonai Logisztika 2015.

Dr. Gáspár Tibor: Fejezetek a Fegyverzeti Szolgálat és jogelődei történetéből IV. rész

Gerlei Tamás - Kukla László-dr. Lovász György: Az Ikarus évszázados története. Maróti Kiadó. Bp., 2007.

Győri J.: A magyar katonai repülés kronológiája Zrínyi Bp., 2009.

Gróf Edelsheim Gyulai Ilona: Becsület és kötelesség Európa Könyvkiadó Bp, 2001. 
Dr. Hajdú Ferenc-Sárhidai Gyula: A Magyar Királyi Haditechnikai Intézettől a HM Technológiai Hivatalig HM TH Budapest, 2005.

Horváth Miklós: 1956 hadikrónikája. Akadémia Kiadó, Budapest, 2003.

Kaposvári László: Az MH logisztikai rendszerének fejlesztési irányai konferencia előadás Budapest 2013.

Kodolányi Gyula: A m. kir. Posta nagyidai és pápai Adcock rendszerü új középhullámú rádió iránymérő állomásai. Magyar Posta XVI. Évf. 5. szám (1942.)

Kovács Ferenc: A Magyar Tanácsköztársaság repülögépei II. Repülés 1968/4. szám

Lantos Antal: Mátyásföld története KHF 28.

Leskó Zsigmond: Bemutatkozik az MH Logisztikai Ellátó Központ. Katonai logisztika 2009./2

Magyar Aviatikai Évkönyv - 1929. (Budapest, József kir. herceg előszavával.)

Dr. Moys Péter: Légiforgalmi irányításunk története.(1920 - 1945)

Nagyváradi - M. Szabó - Winkler: Fejezetek a magyar katonai repülés történetéből Müszaki Könyvkiadó 1986. Bp.

Olasz Lajos: Légi csendőrség Magyarországon a két világháború között és a második világháború időszakában in Magyar csendőrségtörténeti tanulmányok / Parádi József et al. szerk. Szemere Bertalan Magyar Rendvédelemtörténeti Tudományos Társaság Bp. 2015.

Owers, Colin. "'Especially...The D.VII...": The post-1918 career of the Fokker D.VII: Part One". Air Enthusiast,

Repülési Lexikon Akadémiai Kiadó Bp., 1991.

Sárhidai Gyula: Az utolsó Messerschmittek Magyarországon. Haditechnika

Susánszky László: A Magyar Posta szerepe a repülő hírközlésben. Postai és Távközlési

Szíjj Jolán (szerk): Az IHNETOV munkanaplója: vitéz Béldy Alajos vezérezredes Hadtörténeti Levéltárban őrzött irataiból 1941-1943. Petit Real Kiadó, Budapest, 2002. 
Szűcs Miklós: Ezredes voltam 1956-ban a vezérkarnál. Szabad Tér Kiadó, Budapest, 1989.

dr. Takács Ferenc: Halló, itt a mátyásföldi reptér...

Turcsányi Károly - Hegedűs Ernő: A légideszant I. kötet. Puedlo Könyvkiadó, Nagykovácsi, 2007.

Turcsányi Károly - Hegedűs Ernő: A magyar légideszantcsapatok alkalmazásának, haditechnikai eszközeinek és szervezetének fejlödése (1933-45) I-II. rész Katonai Logisztika 2016. évi 3-4. sz.

Dr. Vajda Pál: Nők, akik az eget ostromolták V. Repülés 1968/10. szám

Varga Imre: A M.K. Honvéd Gépkocsiszertár története - Jármüközpont a hadseregben Katonai Logisztika 2015. április

Varga Imre: Adalékok az MH Anyagellátó Raktárbázis történetéhez A Gépkocsi Szertár I. - II. rész. Katonai Logisztika 2016. évi II. és 2017. évi 1. szám

Vesztényi János: A magyar katonai repülés 1920-1942. Magyar Szárnyak Bp. 1993/94

Winkler László: Mátyásföldi repülötér története Bp. 1996. Corvin Kiadó

Winkler László (Szerk.):80 éves a Mátyásföldi Repülőtér Corvin Hírnök Bp., 1996.

Winkler László: Magyar konstrukciók Rákostól napjainkig Repülés 1967.

Zsák Ferenc: A harmadik magyar repülőgépgyár

Zsák Ferenc: A Mátyásföldi repülötér története Aeromagazin 2002. szeptember

Zsille P.: Interkontinentális járat Mátyásföldről Aeromagazin 2007. május 